\title{
Transformation of ecological consciousness in the process of solving global ecological problems
}

\author{
Artur Gudmanian ${ }^{1}$ Liubov Drotianko ${ }^{1}$, Oksana Shostak ${ }^{1}$, Hanna Kleshnia ${ }^{2}$, and Serhii \\ Ordenov ${ }^{1 *}$ \\ ${ }^{1}$ National Aviation University, Liubomyra Huzara ave. 1, 03058, Kiev, Ukraine \\ 2 National Academy for Public Administration under the President of Ukraine, Ezhena Pottier st. 20, \\ 03057, Kiev, Ukraine
}

\begin{abstract}
The article outlines the directions of transformation of ecological consciousness in the process of solving global problems. Insufficient impact of institutional changes on nature management regulation to ensure overcoming of environmental problems is shown. It is emphasized that the main tool for overcoming negative trends in the environmental sphere is the transformation of society's consciousness towards its greening, aimed at achieving optimal interaction between society and nature, the harmonization of material and spiritual life as a real embodiment of the environmental imperative. It should be based on shifting the emphasis of ethical principles - from anthropocentrism to ecologycentrism, to restore the balance between man and the biosphere.
\end{abstract}

\section{Introduction}

The need for a favorable natural environment, sufficient natural resources' quantity and quality, as well as environmental security has been permanently present in human existence. Awareness of this need began when scientists proved that there is an inseparable link between humanity and the environment, independent of human will. At the same time, we think about the state of the environment mainly when material needs are mostly met. Humans begin to take care of the environment when they have everything they need to maintain a decent standard of living. This is due to the law of human development, where vital needs are metfirs, and only then - environmental, cultural, moral ones.

The modern historical period is characterized by the fact that environmental problems of the human existence are gradually coming to the fore. This is largely due to the informatization of society, because, according to research, the more a people are immersed in state of the environment information, the more it increases their ecological selfawareness [1].

The complex ecological environment state significantly affects the economy, which becomes hostage to the environment state. Ecological changes can significantly affect living conditions, causing unforeseen climate change, destruction of ecosystems, depletion

\footnotetext{
* Corresponding author: ordenov@ nau.edu.ua
} 
of natural resources, and thus - their lack. The problem of limited resources with everincreasing consumption has already reached the scale of a global "pandemic". The desire of the world's leading countries to address their narrowly utilitarian economic needs by increasing the consumption of natural resources, especially in "third world" countries, has led to significant damage to the health of current and irreparable consequences for future generations. All this creates a need for close attention to the environmental problems of modern society study, especially in the context of human awareness of the consequences of uncontrolled use of nature. The development of new approaches to solving environmental problems in modern conditions requires new knowledge about the transformation of environmental consciousness, which actualizes this study.

\section{Materials and Methods}

The subject of research specificity determines the methodological basis, which is the theoretical principle of intersubjectivity, in the context of understanding the relationship and interpenetration of the principles of objectivity and subjectivity, with subsequent awareness of the trends of the philosophical understanding of ecological consciousness absolutization. The principle of intersubjectivity presupposes the use of such methodological principle of the relationship between determinism and indeterminism, as well as the principle of the historicism and anti-historicismrelationship.

\section{Results}

The natural environment is the only environment that is favorable for human life. Human is inextricably linked with nature: he breathes air, uses water resources, grows consumer goods on earth, uses subsoil, animal and plant resources. At the same time, in the course of nature's use, man continuously destroys what nature has endowed him with. In particular, scientists pay attention to the decline in soil quality and fertility due to the combined influence of natural and anthropogenic factors. In Ukraine, the rate of depletion of the soil on which food and industrial crops are grown is constant. To restore its fertility, the soil needs proper reclamation.

Table. 1. Indicators of ecological destruction of groups in Ukraine [2].

\begin{tabular}{|l|c|c|}
\hline \multirow{2}{*}{ Indictor } & \multicolumn{2}{c|}{ Significance } \\
\cline { 2 - 3 } & Mlnhectar & $\%$ \\
\hline Decrease in humus content (for the last 35-40 years) & from 3,5 & to 3,1 \\
\hline $\begin{array}{l}\text { Increasing the area of acid soils (over the past 25 } \\
\text { years) }\end{array}$ & over1,8 & 25,0 \\
\hline $\begin{array}{l}\text { Increasing the area of saline soils (over the past 25 } \\
\text { years) }\end{array}$ & over 0,6 & 24,0 \\
\hline Annual growth of eroded arable land & $0,060-0,080$ & $0,1-0,2$ \\
\hline Farmland affected by water erosion & 13,4 & 32,0 \\
\hline Theproportionofagriculturallandsubjecttowinderosion & 6,0 & 14,4 \\
\hline The proportion of saline and alkaline soils & 4,3 & 12,5 \\
\hline
\end{tabular}

Due to the predominance of economic interests over environmental ones, land users try to harvest as much as possible in a short period of time, so they ignore any ecological 
requirements. As a result of irrational use of land resources, the nutritious topsoil is depleted. In other words, farmers are growing more and more products in the soil, which is becoming less and less nutrients, while increasing the content of chemicals, nitrates, pesticides and herbicides. As a result, we consume more and more dangerous and even toxic substances with food, which accumulate in the body and gradually destroy our health and cause many diseases. Similar threatening trends are observed with the use of subsoil, water resources and air pollution.

The UN Summit in 2015 approved the Global Sustainable Development Goals, which became the basis for defining the domestic policies of a large number of states. The threat of a global environmental catastrophe determined the axiological principles of the sustainable development strategy, which was reflected in the current state program "Sustainable Development Strategy 2020" in Ukraine. In our research, we seek to find those points of contact that are directly determined by the priority of maintaining biodiversity and a healthy environment, both in the declared concepts and in those documents that define the actual implementation of the Sustainable Development Strategy 2020.

The paradigm of sustainable development is based on the environmental protection requirements, social justice and the racial and national discriminationabsence. At the same time, the basic provision of the Concept is the need to strike a balance between meeting the modern needs of mankind and protecting the interests of future generations, including their need for a safe and healthy environment.

Ukraine aspires to become a European state and, as A. Fesenko rightly points out, this path turned out to be quite difficult, because the issue is not only structural and economic changes. The ecological aspect is also extremely important. The state of the environment, its quality, ecologically safe methods of conducting economic activity.are quite important for the countries of the European Union [3].

Instead, there are countries where, at the state level, these requirements are ignored, and the concept of sustainable development is embedded in a "convenient" meaning, thus depleting the real thing. In particular, in many "transition" countries, the "development strategy" acquires a formal dimension, and "transition" becomes a certain stationary state that produces "demodernization" [4].

In Ukraine, the term "sustainable development" is used to describe the steady growth of some economic indicators of the country and certain sectors of the economy. Sometimes this list is accompanied by the implementation of single, unsystematic measures to cultivate the environment and improve the human sanitary living and working conditions. This interpretation of the term was criticized by G. Daly. In his opinion, such an approach is not only erroneous, but also extremely harmful, because it is a profanation of sustainable development [5].

It is necessary to organize activities at the systematic level that would minimize the use of artificial substances and technologies which threaten the ecosystem and allow to obtain products with the most natural properties, as well as the production process itself would not disturb the ecological balance. In September 2013, Ukraine adopted the long-awaited Law "On Production and Circulation of Organic Agricultural Products and Raw Materials". It became the basis for technological and organizational changes in the field of organic environmentally friendly agricultural production. However, Ukrainian legislators have reduced the European principles of organic production to formal features, as they have not prescribed any effective mechanisms to ensure them.

This Law is a reflection of domestic ideas about European values. Cosmetic "perestroika", with an implicit desire to leave everything the same, is not able to really improve life, because progress requires a change in worldview, a different attitude to themselves and the world around them. Without such fundamental changes in 
consciousness, it is impossible to build a better life, even following perfect European models.

The ecological crisis is mainly based upon a philosophical and ideological crisis, as well as on a worldview crisis that is not subjected only by economic factors of development. We want to emphasize that of all the universal moral laws that govern humanity, only the ecological imperative goes beyond the human world, and has a superhuman, noosphere significance, which "can be seen as a starting point for the formation of modern scientific discourse and understanding its essence." [6].

From the standpoint of greening, as part of a holistic system of socio-economic management and spiritual development, in the concept of sustainable development, environmental and socio-economic aspirations on a ideological basis in the future are combined. In this context, M. Reimers noted that as long as humanity has become globally integrated physically, politically and economically, but not socially, there is a deepening of existing global problems caused by uneven economic, scientific, technical and social development of developed countries and third world countries, in particular environmental crisis. He believes that in such conditions, the environmental policy of states should become dominant in all world politics, because it determines the possibilities and ways of survival of mankind as a whole, everyone and everyone. In this case, science, politics and ideology go hand in hand, and "ecology is a tool that shapes the worldview of the ecological stage of development of human culture" [7]. This means that in the process of forming economic consciousness, it is necessary to link the development strategy with the strategy of environmental protection, because, in the state ofsystem of restrictions absence, the influence of market mechanisms would continue to determine the exploitation and neglect of social needs. This factor must act as a kind of environmental imperative. It is necessary to identify the state-legal mechanism of environmental management, which, under these conditions, can become a kind of institutionalized means of the environmental imperative at the system level formalizing.

The question might be asked, whydeterioration of the environment and irrational use of natural resourceswould appear along with so many environmental problems, as well as there are so numerous environmental legislation violations? The conclusion is obvious - the mechanism of environmental protection and rational use of nature does not work due toinappropriate level of environmental awareness.

The establishment of stable links between specific environmental conditions in which the system of interaction between human and nature is realized, was defined by our compatriot V. Vernadsky as a noosphere. Defining the noosphere as a new, higher stage of the biosphere associated with the emergence and development of humanity, learning the laws of nature and improving technology, begins to have a decisive influence on the course of processes in the affected area of the Earth, radically changing it in its course [8]. Governance was and remains the most important tool for achieving the desired state, and even more so - a means of bringing the environment in line with human intentions. In this sense, the adoption of the ecological imperative of human behavior, taking into account the real threats determines the deployment of the structure and directions of mankind's socioeconomic development.

Y. Skaletsky and L. Yatsenko, considering the ecological imperative in the context of the social development priority of Ukraine, rightly noted that a necessary condition for preservation and reproduction of the environment is to form the ecological imperative by greening public consciousness and morality, implementing the fundamentally new values, priorities and worldviews [9]. This state consciousness condition was formed before the beginning of the second decade of the XXI century, namely - the notion about environmental risks and dangers of the current state of human assimilation and its technological activities in the global biosystem of the planet began to grow. 
The implementation of a large-scale social project should be based upon aimconcentrated human activity. Human studies in the context of global change is necessary along with understanding of the imperative importances of the globalization era: to think globally - to act locally. However, a number of experts in various fields warn that it would be a big mistake to believe that the environmental problems, including global warming, water pollution, deforestation, can be overcameonly upon the economic and technological levels withoutimproving environmental legislation. Ukraine already has the negative domestic experience in this field.

The ecological crisis in Ukraine is largely tied to the established by technocratic society values and categories, without this insightis quite impossible to change the situation in the environmental sphere for the better. The place of ecology should become decisive in the new system of axiological principles. Thus, we return to the importance of forming environmental awareness as a spiritual basis for overcoming environmental problems. A necessary condition for the environment preservation and reproductionis the origination of the ecological imperative through the greening of public consciousness and morality, fundamentally new values establishment, as well as building socio-economic development priorities and worldviews.

Under modern conditions, environmental policy occupies one of the most important places in world development. This is connected to the human activity intensification, which results in the thermal regime of the planetchanges, the atmosphere and the oceanscomposition, the radioactivitybackground, as well as the ratio of water and land in some regions. This impact negative consequences can lead to an ecological crisis, which is already manifested in the environment pollution with toxic waste, lack of food and energy resources and, as a consequence, - a decrease in the individual species number in the population and changes in its structure, genetic stock, demographic imbalance. Disappointing predictions about the accumulation of these negative factors cause the danger of the transition of an ecological crisis into an ecological catastrophe, this may lead to the entire civilization catastrophe.

Meanwhile the Earth population grows as well as its living standards, which leads to increasing of the consumption in a world where natural resources are limited and mostly non-renewable, at current rates the use in the coming decades will lead to irreversible environmental and resource collapse. Ukrainian researcher V. Buryak notes that the psychological component of dependence on demonstrative and constant consumption has become apparent worldwide after the onset of the global economic crisis in the summer of 2008 [10]. Modern marketing strategies are integrated into the consumer society needs, in addition toits immediate goal - money laundering from consumers' pockets. But it has other "side" effects in the form of negative integrative impact on anthroposociogenesis and environmental status.

British and American scientists M. Hurst, H. Dittmar, R. Bond and T. Kasser conducted a research upon the materialistic values influence on the individual attitude toward nature protection and the ecological behavior. The New Ecological Paradigm (NEP), popular in foreign studies, was used to measure the criteria of personal attitude toward the environment and ecological behavior. Material Values Scale was used to measure values. In the process of the surveys scientists have found that entities with a high level of material values dominance lead to a lower level of environmental attitudes and environmental behavior than entities where material values are not in a priority [11]. Thus, the "consumer society" materialist valuessignificaly impact the affective and discursive components of environmental consciousness, which, in determines the cognitive component. Proponents of the materialist value system are simply unable to comprehend in full the damage done by the of the "consumer society"attitudes toward the environment. 
The question of the interdependence of economic, environmental and socio-cultural nature problems as well as their integrative, comprehensive study is raised by M. Moiseev. Taking V. Vernadsky's teachings on the biosphere and its gradual transition to the noosphere based on the transformation of human environment as a foundation the scholar discusses the future role of human as a major factor in biosphere evolution. Moiseev developed the theory of "ecological person "through the prism of a combination of various factors of life: natural, scientific, technical, economic, socio-cultural, while taking into account, of course, differences in goals, conflicting aspirations. He described the values of people living in different political, social and natural conditions. At the same time, the scholar believed that it was the "environmental imperative" that forced people to seek appropriate decisions to ensure the "coevolution of human and the biosphere". Moiseev calls it "a condition necessary for the preservation of humanity in the biosphere, for human survival on the planet" [12]. Defining the ecological imperative as "the limit of permissible human activity, which no one has a right to violate under any circumstances" [13], it regulates the new principle of human interaction with nature.

The ecological imperative is often understood as a form of prohibitions and restrictions that apply to any human activity to preserve wildlife andplanet species diversity, protect the environment from excessive pollution as unconditional priorities. Y. Skaletsky, V. Bazylevych [14], Y. Tunitsa, E. Semenyuk [15] studied the ecological imperative in the context of its impact on the society development strategy. By analogy with Kant's categorical imperative, scientists recognize the requirement to comply with the rules of environmental protection, a set of priority and mandatory restrictions on human activity as such that can lead to catastrophic consequences for humanity. However, in our opinion, such a critical form of ecological imperative does not quite adequately reflect its axiological significance and, accordingly, cannot fully outline its impact on the transformation of ecological consciousness.

We believe that the transformations of environmental consciousness occur under the interdependent influence of informational, ideological and psychological components, which, in turn, are influenced by spiritual, cognitive and socio-cultural factors that dominate society.

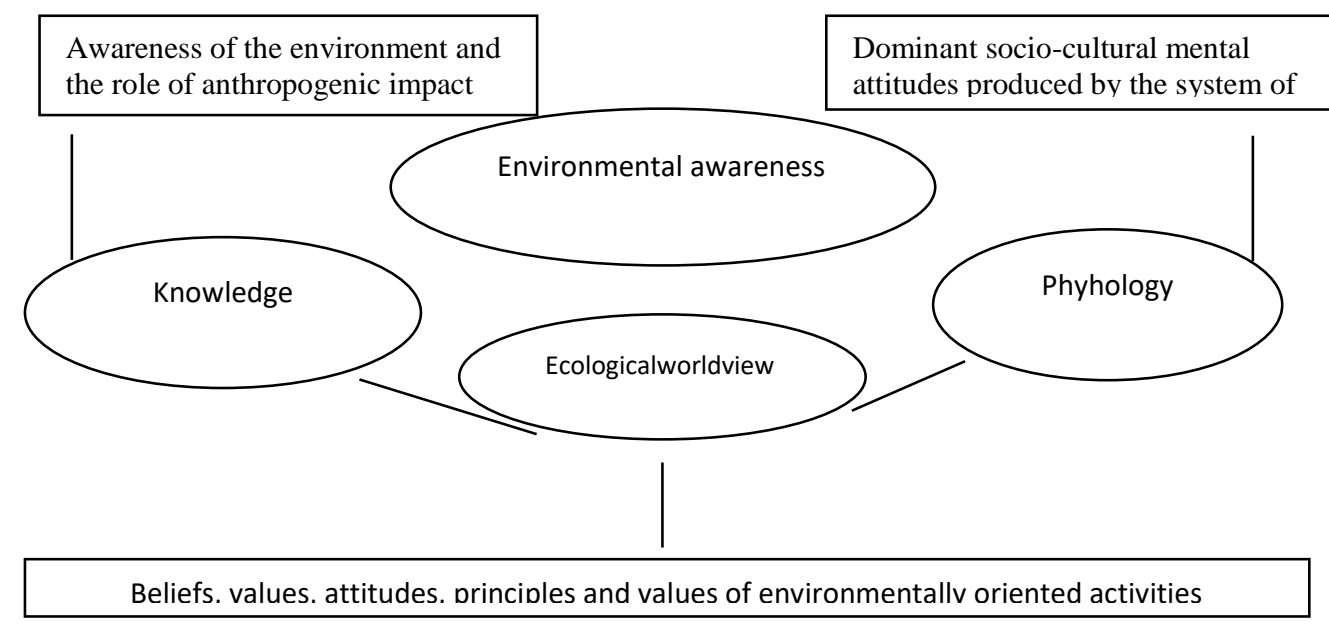

Fig. 1. The main components that influence the transformation of environmental consciousness.

American naturalist T. Berry, criticizing social institutions for their inability to ensure human coexistence in harmony with the natural environment, said: "The environment does not belong to the human community, and the ecological imperative is not a category derived from human ethics. On the contrary, human ethics is derived from the ecological 
imperative, because the basic ethical norm is to ensure the prosperity of the community and each individual in it" [16, p. 105]. We support this disclosure of the ecological imperative, because we believe that it manifests itself in the ethical system of mankind as a rejection of the current destructive course and the desire for a more natural form of existence of civilization.

Based on a broad understanding of the relationship between human and nature, the ecological imperative requires a shift in the emphasis of ethical principles - from anthropocentrism to ecocentrism, which will lead to the restoration of the balance between man and the biosphere. In this context, G. Green, developing Berry's ideas, said: "We need laws that recognize the rights of non-human components of the Earth's biosphere, and ethics that give human communities a code of rules for interaction with the environment" $[17$, p. 12].

According to $\mathrm{Yu}$. Tunitsa, one of the key factors of sustainable development of the state and consolidation of society is based around solving of environmental and economic problems. The environmental imperative involves the introduction of a new way of management, close to the laws of nature and based on rational use, preventive protection and timely reproduction, natural living environment and natural resources [18, p. 146].

Among the threats to environmental security, the National Security Strategy of Ukraine states excessive anthropogenic impact and a high level of man-caused load on the territory of Ukraine. At the same time, the Strategy lacks a vision of the development of basic components of nature management: natural resources (forests, water, land, animals, subsoil, complexes of biogeocenoses and biogeochemical cycles) as a necessary condition for the existence of society. There is no attention to the problems of water resources, climate challenges, catastrophic threats associated with soil erosion and dehumidification, forest degradation, depletion of water resources and mineral resources. It is quite significant that in the Strategy of Sustainable Development of Ukraine until 2020 [19], among the 25 indicators identified, there is none that would relate to the environment.

The ecological imperative determines the requirements for the transformation of ecological consciousness, the formation of appropriate environmental policy and its implementation in all spheres of life. At the same time, given the general state of resources, the focus should not even be on the person who really has the right to a healthy and fruitful life in harmony with nature; it is necessary to ensure equal opportunities for development and preservation of the environment for both current and future generations; environmental protection must become an integral part of the overall socio-economic process and cannot be considered in isolation.

In contrast to the current practice, the emphasis should be shifted to the implementation of measures to green economic activity, primarily - to eliminate the causes of negative human- made impacts, rather than their consequences. Socio-economic development should be aimed at improving the quality of human life within acceptable limits of ecosystemseconomic capacity. It is extremely urgent to implement measures to greening the human consciousness and worldview, the system of upbringing and education. These requirements reflect the essence of the environmental imperative, the inextricable and organic link between the social, environmental and economic goals of sustainable development.

The need to form a fundamentally new worldview that would reflect the organic relationships and dependencies between man and nature becomes obvious for thecivilizationsurvival and development. The formation of an ideology indicates the ways to overcome contradictions between economic and ecological systems and provided a constructive solution to the problems of sustainable development.

Based on the noosphere teachings of our great compatriot V. Vernadsky, the new ecological and economic theory and the principle of sustainable development is adopted by 
a lot of countries. Only an ecologically conscious society is able to overcome the protracted ecological and economic crisis and ensure normal ecological and socio-economic living conditions. Ukraine. It is about forming an ideology that reflects the causal relationships and dependencies between the state of natural resources consumption, the quality of environment, on the one hand, and socio-economic development and human health, on the other.

An extremely important factor, which is especially acute in the conditions of environmental degradation and depletion of natural resources, is the feeling of common destiny. Awareness of the vital need to act in accordance with the environmental imperative is a necessary condition for overcoming negative trends in the environmental sphere. The main tool for this is the transformation of society's consciousness towards its greening, aimed at achieving optimal interaction between society and nature, the harmonization of material and spiritual life as a real embodiment of the ecological imperative.

Thus, solving global problems cannot be simple and painless, because historical traditions, economic interests of influential political forces are revealed, outdated stereotypes are suppressed, and various contradictions between different countries flare up. The ways of the human society in every historical movement in solvingvital, and even more fateful problems are complex, alternative and diverse. To overcome the existing and new contradictions of global scale, humanity must, first of all, abandon the confrontation in thinking, gradually producing the so-called global environmental consciousness, which is based on the recognition of heterogeneity, multipolarity, natural dimension and ambiguity of modern human civilization.

\section{Discussion}

Traditionally, environmental problems belong to a set of global problems, they are generally have negative consequence of the industrial development in the Modern era. V. Lukyanets and O. Sobol note that "Moloch of Modernism" - scientific and technological progress - required great sacrifices in the postwar years. Among these victims, they call the appearance of ozone holes, acid and radioactive rains, pollution of the oceans, soil and atmospheric poisoning, Chernobyl, AIDS, the greenhouse effect, etc., which "globally threaten the existence of anthropy in the world" [20, p. 43]. Researchers believe that these Modern era negative consequences of scientific and technological progress have convinced mankind of the perniciousness of further taming of nature, despite the positive moments that Modernism has brought to society in its economic development. "Therefore, the purpose of modern post-non-classical science is not so much the cognitive value of knowledge about the human external world, but the priorities definition of socio-cultural nature" [21].

Concerns about the growth of environmental problems are also traced in the conclusions of A. Gore, who draws attention to the shortcomings of the modern capitalist system, noting that "the bitter truth is that our economic system is partially blind... Its calculations often do not take into account the value of buy or sell: clean water and fresh air, the beauty of mountains, forests with diverse flora and fauna, etc. It is the partial blindness of the current economic system that is the powerful force behind irrational decisions concerning the ecology of our planet" [22, p. 560]. Considering that further pollution is unacceptable, he proposes to take concrete radical measures at the governmental level.

Given that the environmental problems posed by technocratic civilization have a global dimension, it is impossible to escape them, as well as to return to "nature". Global environmental issues are not solved on an individual level. You can't say I don't like it or it doesn't concern me. It is necessary to transform the public environmental consciousness, 
the formation of a new, nature-oriented mentality and morality of human, which will act as a spiritual basis for overcoming global environmental problems.

\section{Conclusions}

The transformation of economic consciousness must take place along the lines of the development strategy associated with the strategy of environmental protection, because, in the system of restrictions absence, the influence of market mechanisms determines the exploitation and neglect of social needs. The implementation of these strategies is possible by optimizing the relationships by transforming environmental consciousness under the interdependent influence of informational, ideological and psychological components. Those components are influenced by spiritual, cognitive and socio-cultural factors that dominate in the society. Saving humanity from global environmental threats is possible only if the emphasis is shifted on ethical principles - from anthropocentrism to ecologycentrism, which will lead to the balance between man and the biosphere restoration.

\section{References}

1. S. Otto, G. Kaiser, Journal of Environmental Psychology, 40, 331-338 (2014)

2. L. H. Melnyk, Ekolohichna ekonomika. [Ecological economy] (Universytetska knyha, Sumy, 2008)

3. A. M. Fesenko, Bulletin of the Petro Vasylenko Kharkiv National Technical University of Agriculture, 156, 243-250 (2015) [in Ukrainian]

4. S. Ordenov, H. Kleshnia, Demodernization as a hybrid form of modernization oftraditionalist society in the globalized world. Humanities \& Social Sciences Reviews, 7(4), 1241-1247 (2019) https://doi.org/10.18510/hssr.2019.74171

5. H. Daly, Beyond Growth: The Economics of Sustainable Development (Beacon Press, Boston, Massachusetts, 1997)

6. L. Drotianko, S. Yahodzinskyi, V. Vernadsky, E3S Web of Conferences, 135, 03079 (2019) ITESE-2019 https://doi.org/10.1051/e3sconf/201913503079

7. N. F. Rejmers, E`kologiya (teorii, zakony`, pravila, princzipy` i gipotezy`). [Ecology (theories, laws, rules, principles and hypotheses) (Rossiya molodaya, Moscow, 1994) [in Russian]

8. E. A. Afonin, O. L. Valevskyi, V. V. Holub Vdoskonalennia derzhavno-upravlinskykh vidnosyn $v$ umovakh transformatsii ukrainskoho suspilstva. [Improving public administration relations in the conditions of transformation of Ukrainian society] (NADU, Kyiv, 2012) [in Ukrainian].

9. Yu. M. Skaletskyi, L. D. Yatsenko, Stratehichni priorytety, Strategic priorities, 1 (18), 44- 48 (2011) [in Ukrainian]

10. V. V. Buryak, Dinamika kul`ury`v e`pokhu globalizaczii: noosferny`j kontekst. [The dynamics of culture in the era of globalization: noospheric context] (DIAJPI, Simferopol, 2011) [in Ukrainian]

11. M. Hurst, H. Dittmar, R. Bond, T. Kasser, Journal of Environmental Psychology, 36, 257-269 (2013) 
12. N. N. Moiseev, E`kologiya i obrazovanie. [Ecology and education] (YuNISAM, Moscow, 1996) [in Russian]

13. N. N. Moiseev, Voprosy` filosofii, Questions of philosophy, 1, 3-30 (1995) [in Russian]

14. V. Bazylevych, Visnyk Natsionalnoi akademii nauk Ukrainy, Bulletin of the National Academy of Sciences of Ukraine, 8, 15-19 (2010) [in Ukrainian]

15. Yu. Tunytsia, E. Semeniuk, T. Tunytsia, Visnyk Natsionalnoi akademii nauk Ukrainy, Bulletin of the National Academy of Sciences of Ukraine, 2, 8-24 (2008) [in Ukrainian]

16. T. Berry, The Great Work (Three Rivers Press, New York ,1999)

17. H. Green,The Ecozoic Reader, 1, 1 (2000)

18. Yu. Iu. Tunytsia, Naukovyi visnyk NLTU Ukrainy, Scientific Bulletin of NLTU of Ukraine, 21(19), 146-156 (2011) [in Ukrainian]

19. Stratehiia staloho rozvytku «Ukraina - 2020» [Sustainable Development Strategy "Ukraine - 2020"]. http://zakon5.rada.gov.ua/laws/ show/5/2015 [in Ukrainian]

20. V. S. Lukianets, O. M. Sobol, Filosofskyi postmodernizm. [Philosophical postmodernism] (Abrys, Kyiv, 1998) [in Ukrainian]

21. L. Drotianko, M. Abysova, N. Chenbai, T. Shorina, E3S Web of Conferences, 157, 04003 (2020) https://doi.org/10.1051/e3sconf/202015704003KTTI-2019

22. A. Gor, Zemlya na chashe vesov. V poiskakh novoj obshhej czeli [Earth on a bowl of scales. In search of a new common goal]. Novaya postindustrial'naya volna na zapade, A new post-industrial wave in the west (Academia, Moscow, 1999) [in Russian] 